\title{
INTERPRETAÇÕES SOBRE VOLTAIRE: \\ A HISTÓRIA DE JENNI OU O SÁBIO E O ATEU
}

Estela Araújo Silva ${ }^{1}$

RESUMO: O objetivo deste trabalho é de apresentar a obra de François-Marie Arouet, Voltaire (1694-1778), seu pseudônimo, e iremos apresentar uma interpretação de $O$ sábio e o ateu da forma mais clara e objetiva possível. Nessa obra, apresenta a visão da importância da existência de Deus, da mesma forma que também apresenta as ideias ateístas pelas quais não se acredita em Deus. Voltaire era um deísta (aquele que não precisa de intermediação de religião para se relacionar ou ter fé com Deus), não era ligado à religião, e ao contrário, era crítico à igreja católica, pois a considerava, alienadora e desonesta. Para ele, a existência de Deus é necessária para se manter a ordem social, daí a vem sua frase: "Se Deus não existisse seria preciso inventá-lo". Na obra $A$ História de Jenni ou $O$ sábio e o ateu, Voltaire apresenta de forma simples suas ideias a respeito da existência de Deus e as ideias dos ateus sobre o ateísmo, o que ele considerava ser um movimento modista. A obra apresenta ideias a respeito da tolerância e à liberdade de expressão. $\mathrm{Na}$ obra, Voltaire encarna o personagem Freind, um homem de atitudes sábias e tolerantes, que vai tentar trazer seu filho Jenni e seus amigos de volta à vida honesta. É nesse intento que se tenta provar a existência de Deus, sem passar a ideia de ser um fanático religioso, pois sua intenção de escrever essa obra foi justamente mostrar que não era um beato.

Palavras-chave. Ateísmo; Moralidade social; Deus.

\section{Introdução}

Voltaire (1694-1778) é um importante filósofo do XIII, e é um importante contribuinte do Iluminismo, crítico severo ao poderio da igreja, escreveu $O$ sábio e o Ateu, aos 81 anos em 1775, três anos antes de sua morte, mas nem por isso é uma obra menos interessante que seus outros escritos.

Embora não estejam entre as obras mais famosas de Voltaire, tal obra trás as mesmas ideias de suas outras, como por exemplo, O tratado da Tolerância, em que faz crítica a intolerância religiosa, e em contos como $O$ Candido, O ingênuo, em que questões da maldade são levantadas, essas ideias são retomadas em A História de Jenni, porém, o autor diminui o tom irônico e

\footnotetext{
${ }^{1}$ Graduanda em Filosofia pela Cead UFPI
} 
sarcástico, critica os dogmas do catolicismo e fanatismo religioso com força nesta obra. No entanto, a carga maior de veneno recai sobre o ateísmo, pois é voltada justamente para a ideia de defesa da existência de Deus, e valorização da ordem social, com relação aos judeus, que os recrimina pelos males cometidos, mas os defende como seres humanos.

Nesta obra, são contadas as histórias de aventuras do jovem Jenni, filho do pastor anglicano Friend, aventuras essas que por muitas vezes contrariavam seu pai, respeitado e admirado homem com atitudes que revelam sabedoria. Friend, com seu jeito eloquente, se opôs a prática antropofágica e conseguiu convencer homens selvagens abandonarem a prática de comer carne humana. Com amor e demonstração de afeto, sem precisar reprimir o seu filho com palavras ou punições, que pudessem impor alguma mudança de comportamento, mas deixava-lo examinar por si mesmo.

Esta é uma obra que nos faz confrontar a nós mesmos no que diz as nossas crenças, nesse sentido, pode reforçar a crença de um Teísta ou pode confirmar mais ainda os motivos pelo qual não se acreditar em Deus. Pois em um diálogo entre Freind e o jovem ateu Briton, os dois posicionamentos são apresentados sempre havendo um diálogo amistoso com relação aos pensamentos opostos. Voltaire deixa claro que nessa obra que o seu posicionamento é deísta, ou seja, admite a existência de Deus, mas rejeita a ideia de revelação divina, considerando a razão como a única via capaz de nos assegurar da existência de Deus, rejeitando, para tal fim, o ensinamento ou a prática de qualquer religião organizada.

Para ele, negar a existência de Deus é algo absurdo, pois diz: "Deus existe como a coisa mais verossímil que os homens podem pensar e a proposição contrária como uma das mais absurdas" (VOLTAIRE, 1978, p. 68).

$\mathrm{Na}$ obra também, são apresentadas questões de valor moral, em que a vida justa e honesta, longe da maldade, é valorizada. Tudo isso é caracterizada através experiência vivida por, Jenni, um rapaz de boa aparência, que despertava paixão nas moças.

\section{O sábio e o ateu}

O padre inquisidor Dom Jerônimo Bueno Caracurador, o qual se mostrava ser de má conduta, condenou o jovem Jenni à fogueira, por este ter se envolvido com sua amante, Dona Boca Bermeja. Esta, ao ver o belo rapaz se apaixonou profundamente pelo jovem, quando questionada por sua amiga Las Nalgas se seria infiel ao Dom Jerônimo Caracurador, não hesitou confirmar sua vontade de ter o rapaz.

Para tentar justificar a essa sentença Dom Jerônimo diz ao pai do jovem, o Doutor em Teologia, Membro do Parlamento e da Sociedade Real, Freind, que achava que o jovem era 
Judeu. Isso the causou ouvir um bom sermão pelo Senhor Friend, com respeito ao fato de o jovem ser ou não judeu, não era justificativa para condenar alguém à fogueira, pois o valor de alguém não está atrelado à nacionalidade ou à religião.

A forma como Friend consegue resgatar seu filho da vida desonesta é mostrada como uma forma pedagógica no sentido de como educar os filhos, isto é, para os que desejam olhar assim. Mostra um pai preocupado em educar seu filho que está voltado às paixões desenfreada,s ao pagar as dívidas do filho aos bancários, ao livrá-lo da morte e demonstrar com atitudes o caminho que considera correto seguir.

$\mathrm{Na}$ tentativa de livrar seu filho dessa vida guiada por suas paixões, Freind pretende casar seu filho, com a jovem Primorose, que logo se apaixona pelo rapaz e os dois assumem compromisso. Contudo, a Senhora Clive-Hart quando soube do noivando de Jenni, enciumada arquiteta, traça o plano de acabar com a vida da noiva de Jenni e eventualmente com a de seu marido, envenenando-os.

Clive-Hart, como costume das mulheres libertinas, amava Jenni, mas o traía com outros dois libertinos, entre eles Birton. Todos viviam na mesma situação de depravação. Tendo o seu plano consumado, Clive-Hart foge com Jenni, Birton e seu grupo de amigos ateus. O marido de Clive-Hart, por ser um alcóolatra, e ter a saúde debilitada pelo vício, morre logo após o envenenamento, a Senhorita Primorese, no entanto era jovem e de boa saúde e ao ficar aos cuidados do Senhor Meade, se recuperou gradativamente, pois este possuía o conhecimento em diversos venenos.

Com a onda de ideias ateístas aumentando, Jenni se junta a esse grupo e começa a participar de reuniões na casa da senhora Clive-Hart, os quais seguiam ideias epicuristas, em que não a acreditavam na imortalidade da alma, no tentando, poderiam fazer o que quisessem, pois o que importava era viver feliz.

Ao descobrir que o filho tinha fugido, Freind resolve ir à trás de seu filho, no Conto, Voltaire dá espaço para o debate sobre ateísmo e a sua tolerância, onde ambos, Freind e Birton, têm a oportunidade de defender suas convicções de maneira livre. Pois Voltaire era um defensor da liberdade de expressão. Entendia que a vida desordeira e as consequências desses atos, podem ser resultados da crença em Deus ou não. Se as pessoas assim começarem a se comportar sem Deus, há caos e desordem. Nisso, a existência de Deus é necessária para que se haja o bem de todos. No entanto, em dado momento de sua obra, fica o entendimento de que não acreditar indubitavelmente em viver de maneira honesta, acaba levando os filósofos à miséria como Spinoza e Hobbes. 
Jenni viveu as mais vibrantes aventuras, em que chegou a cometer até mesmo assassinatos, tornou-se amante de mulheres comprometidas e ainda por cima fugiu com sua amante Clive-Hart, mesmo que ingenuamente. Visto que esta planejou o assassinato de Primorose, com quem ele estava noivo, sem que Jenni soubesse. Em sua fuga, andavam pelo mundo, fazendo tudo o que desejavam sem pensar em suas consequências, até encontrarem um grupo de Selvagens, que os fizeram prisioneiros, onde mataram Clive Hart e comeram sua carne. Quando finalmente Freind encontra seu filho e seus amigos, e fica sabendo de como tudo aconteceu durante a aventura desses jovens, ao saber o que aconteceu com Clive Hart, expressa sua doutrina dizendo achar que Deus usa as circunstâncias da vida para punir os malfeitores.

Assim como também expressa almejar que o exemplo de Clive-Hart sirva de exemplo para que, aqueles jovens corrigem seus erros. Em tom de deboche, Birton diz que já não se importar com Clive Hart, Birton é um rapaz sagaz e sarcástico, diferente dos jovens de sua idade, pois este se mostrava interessado no conhecimento, embora, tenha cometido o erro de não se aprofundar nos estudos a respeito do próprio ateísmo.

$\mathrm{Na}$ volta à Inglaterra, Freind e Birton começam a conversar, o diálogo está divido em questões como: por que Deus que pune alguns e outros não? Natureza, tudo é arte, a maldade, o mau uso da liberdade, virtude, leis gerais. Birton faz referência ao um livro de um frenchman ${ }^{2}$, que diz que nada existe, senão a natureza, Birton diz acreditar só na natureza.

Em relação à maldade, Birton questiona por que Deus pune a uns e a outros não? Como pode existir um ser preocupado em punir mulheres e homens maus e deixar outros impunes? Como é o exemplo de pessoas que foram más, mas viveram toda sua vida feliz. Ao questionar também a bondade de Deus, Birton fala que este mundo é defeituoso, pois acontecem desastres naturais além das pestes e doenças que assolam o mundo, questiona sobre a virtude, onde ela pode ser encontrada? Se Deus fez tudo, os venenos são obras dele, e ele é o Senhor de tudo, ele faz tudo, como pode ele dirigir a mão do carrasco que corta a cabeça de alguém, Birton diz não aceitar a ideia de um Deus homicida.

Freind argumenta que tudo é arte, que existe um oreri ${ }^{3}$, e podemos ver a arte divina e ter certeza de que existe um escultor, mesmo sem vê-lo. Esse pensamento se confirma no que Voltaire diz.

Quando vejo um relógio cujo ponteiro marca as horas, disso concluo que um ser inteligente montou as engrenagens para que o ponteiro marque as horas. Assim quando

\footnotetext{
${ }^{2}$ Palavra que se refere a francês. Birton refere a um livro escrito por um francês que diz que nada existe, senão a natureza, essa crença relaciona-se ao panteísmo que faz uma identificação entre o universo e Deus, ambos estão concebidos, como uma realidade integrada.

${ }^{3}$ Artífice ou artesão, Voltaire usa o termo oreri pra designar a Deus, como sendo o artista que criou o mundo.
} 
considero as engrenagens do corpo humano. Concluo que um ser inteligente montou os órgãos para serem recebidos e nutridos por nove meses na matriz: que os olhos nos são dados para ver, às mãos para segurar, e assim por diante. (Voltaire, 1978, p.63).

Freind concorda que há mal na terra, mas que tudo foi feito para o seu determinado fim, explica que o clima de cada região foi feito adequado a cada morador adequado. As pessoas, animais vegetais tem um espaço especifico no globo. As pestes e doenças vêm por que nós e nossos pais abusamos de nossos corpos, o excesso não é bom, por isso, Freind alega a necessidade de leis morais.

Existe muito mal no mundo, o mal moral e físico, mas a existência de Deus é real e é certa. O problema do mal e do sofrimento humano, não é suficiente para provar que Deus não existe, é uma dificuldade a ser superada pela reflexão filosófica. Os homens fazem mal uso de sua liberdade. O mal físico é resultado, por poderem executar suas próprias vontades. É verdade que há crime, o crime está em toda parte e nisto também se tem virtude. Existem pessoas más e pessoas boas, o crime sempre existiu e assim as virtudes crime, mas fez ao homem e os deram as leis do movimento; essas leis eternas do movimento ${ }^{4}$ são igualmente executadas pela mão do homem caridoso. Se essas leis não tivesse sido nos dadas seriamos como máquinas.

Deus não recompensa de imediato o homem que faz o bem do mesmo jeito que não pune de imediato quem faz o mal. "O sol brilha para todos, bons e maus". Tendo o lado físico de uma ação má, é efeito das leis gerais imposta pela mão de Deus à matéria. Todo o mal moral da ação criminosa é efeito da liberdade de que o homem abusa. Por meio de sua justiça Deus pode recompensar os bons. Deus se dar a conhecer a nós por meio de suas obras e de nossa consciência. A existência de Deus, não é uma questão de fé, mas de razão, algo possível de ser demonstrado por meio do próprio funcionamento das leis da natureza.

Voltaire acredita que a punição para os malfeitores acontecem mediante a violação das leis gerais de Deus, segundo essas leis o homem, pode cometer um crime, mas em algum momento de sua vida virá à punição sobre o criminoso.

$\mathrm{Na}$ obra A bistória de Jenni se observa que pelas atitudes de Clive e seus amigos, as crenças que são voltadas ao panteísmo, onde a visão de Deus e natureza é vistas como sendo uma única substância, acabam também por ser um amoralismo em que se pode viver numa busca desenfreada dos prazeres. Característica semelhante de um hedonismo marcado pela ideia de que não há pecado. Essa prática é condenada por Voltaire, que critica a filosofia materialista ateísta, por ser voltada a uma filosofia imoral e amoral, a qual não se acredita na existência de Deus.

\footnotetext{
${ }^{4}$ São leis eternas de Deus que está relacionada às leis gerais. Para Freind Deus não é responsável pelo mal, mas apenas permite pelas leis do movimento, que o homem mal faça o mal e que o homem bom faça o bem.
} 
Nisso, o naturalismo em que somos parte da Natureza e as nossas escolhas e desejos são determinadas por leis de causa e efeito e não pela ideia de livra árbitro, leis gerais ou leis do movimento de Voltaire.

O diálogo entre Freind e Birton, finaliza com Birton reconhecendo que o grande Ser, o Senhor da natureza é eterno e pede perdão por ter duvidado da Sua virtude, reconhece que abusou de sua liberdade e questiona como Deus poderia puní-lo sendo que o Próprio Deus o designou àquelas paixões?

Freind responde que Deus o deu aquelas paixões as quais ele poderia fazer o bem e o mal, e diz que não sabe quando ele irá ser punido e nem sabe como será punido, mas sabe que Deus poderá puní-lo. E sugere que ele deve viver de forma honesta.

Freind continua falando sobre os males causados pelo ateísmo, cita exemplos ocorridos no século XV na Itália mostrando os estragos causados por reis ateus e pelo fanatismo religioso. Voltaire diz que o ateísmo e o fanatismo são dois polos de horror. Para ele, é mais fácil curar um ateu do que um fanático. Voltaire define o fanatismo da seguinte maneira "O fanatismo está para a superstição como o arrebatamento para a febre ou a raiva para a cólera. Aquele que experimenta êxtases, visões, que toma os sonhos por realidades e as suas imaginações por profecias, é um entusiasta; aquele que sustenta sua loucura pelo assassinato, é um fanático" (VOLTAIRE, 1968, p. 105).

Ao término do discurso de Freind, Birton e seus amigos convertem-se a Deus, w este é um momento em que todos se veem envolvidos pela emoção. Jenni em tudo refletia sobre os acontecidos que o envolviam, em prantos de lágrimas, confessa seus erros. Na volta à Inglaterra, Primorose que estava quase à morte, pelo envenenamento que Clive-Hart lhe causou, já estava recuperada de sua enfermidade e casa-se com o agora redimido Jenni.

Voltaire acredita é que a crença em Deus que limita os males causados, quem usa do ateísmo como uma maneira a viver e de abusar de suas liberdades, é justamente por isso que ele diz "Se Deus não existisse seria preciso inventá-lo, porém a natureza proclama a sua existência". (VOLTAIRE apud REALE, 2005, p.257).

Sua existência se confirma por meio das evidências de que a natureza nos deixou a existência de um artesão supremo. A existência de Deus é necessária, para limitar o homem, e colocar ordem no mundo, pois a crença em um Deus que pune, levaria a um equilíbrio social, em que a maldade estaria subjugada, sobre a possibilidade de houver punições, a quem assim se comportar.

O Sábio e o ateu ou a História de Jenni pode ser vista de maneira pedagógica, sobre a forma de como educar filhos, de maneira crítica, pois, ao se ter lido as várias obras de Voltaire, e se deparar 
com uma obra que parece ser esquecida, é natural que alguém, possa olhá-la de forma crítica sobre sua religiosidade e tolerância. Aos que procuram uma obra de uma leitura de fácil compreensão sobre o tema, Ateísmo, e Teísmo, esta é uma boa opção de leitura.

\section{Referências bibliográficas}

REALE, Giovanni. História da Filosofia: de Spinoza a Kant. São Paulo: Paulus, 2005.

VOLTAIRE, Tratado de Metafísica. (Os pensadores) 2. Ed. São Paulo: Abril culture, 1978. Euvres complètes, éd. Voltaire Foundation, Oxford: Oxford University Press. 1968.

. História de Jenni ou O ateu e O Sábio. Coleção Grandes Obras do Pensamento Universal - 49: Editora Escala. 2010. 